\title{
Research Article: Relationship between socio-economic characteristics of farmers with perceived attributes of soybean production technologies
}

\section{S.K. JAMANAL AND SYED SADAQATH}

Article Chronicle: Received :

19.07.2017;

Accepted :

03.08.2017

KEY Words:

Socio-economic change, Perceived attributes, Production technology

Author for correspondence :

\section{S.K. JAMANAL}

Department of Agricultural Extension Education, College of Agriculture, University of Agricultural Sciences, DHARWAD (KARNATAKA) INDIA

Email : sidjamanal@ gmail.com

See end of the article for authors' affiliations
SUMMARY : The present study was an attempt to compare the relationship between socio-economic characteristics of Soybean growers with perceived attributes of Soybean production technologies. The study was an "expost-facto" research carried out in Dharwad district of Karnataka Stateduring the year 2013-14. The study covered 15 villages from 3 talukas of Dharwad district to form a sample of 150 respondents. A pre-tested structured interview schedule was used to collect the data from the respondents by personal interview method.The results indicated that, Age had a non significant relationship with perceived attributes of soybean production technologies.Education, land holding extension contact, mass media participation, innovative proneness, scientific orientation and area under soybean crop had a positive and highly significant relationship with perceived attributes of soybean production technologies.

How to cite this article : Jamanal, S.K. and Sadaqath, Syed (2017). Relationship between socio-economic characteristics of farmers with perceived attributes of soybean production technologies. Agric. Update, 12(TECHSEAR-7) : 1957-1960; DOI: 10.15740/HAS/AU/12.TECHSEAR(7)2017/1957-1960. 